\title{
PELATIHAN KECAKAPAN VOKASIONAL UNTUK MENINGKATKAN KEMANDIRIAN SOSIAL EKONOMI INDIVIDU EKS PSIKOTIK DI UPT REHABILITASI SOSIAL EKS PSIKOTIK PROVINSI JAWA TIMUR
}

\author{
Muh. Chotim, Ratih Christiana *) \\ Andika Hady Pratama **)
}

\begin{abstract}
Ex-psychotic individuals encounter many difficulties in the process of socializing and returned to the environment, so that the necessary training skills before returning to the family and society. The purpose of this study was (1) To determine the effort to improve the social and economic independence of individual ex-psychotic through vocational skills training in the Social Rehabilitation Unit Ex Psychotic Social Service of East Java Province, (2) To determine the effectiveness of vocational skills training to improve social and economic independence of the individual ex-psychotic The Social Rehabilitation Unit Ex Psychotic Social Service of East Java Province.Writing method using a case study approach to field studies (field research) combined with literature (library research). This community service is a descriptive research, data analysis using qualitative analysis with interactive model. The analyzed data is the data rate of socio-economic independence of individuals before and after the psychotic ex vocational skills training.This research with two activities that make the carpet of material raffia rope and wooden crafts. Potential outcomes include training in order to improve their socioeconomic independence, product copyrighted works, a national scientific journals and strengthening the role of counselors and social services functions.
\end{abstract}

Keywords: Independence, Social, Economic, Ex Psychotic, Vocational

* Muh. Chotim \& Ratih Christiana adalah Dosen Program Studi Bimbingan dan Konseling Fakultas Ilmu Pendidikan IKIP PGRI MADIUN.

** Andika Hady Pratama adalah Mahasiswa Program Studi Bimbingan dan Konseling Fakultas Ilmu Pendidikan IKIP PGRI MADIUN. 


\section{Pendahuluan}

Fenomena yang terjadi di masyarakat, individu eks psikotik banyak menemui berbagai kesulitan pada saat bersosialisasi dan kembali pada lingkungan tempat tinggalnya. Oleh karena itu banyak panti rehabilitasi yang berusaha mengupayakan berbagai cara, guna meningkatkan kemandirian yang menyeluruh khususnya mengarah pada aspek sosial dan ekonomi. Melalui suatu proses pelatihan kecakapan vokasional yang diprogramkan dan terstruktur, menjadi salah satu pilihan yang efektif untuk mendidik dan melatih kemampuan belajar ke arah kemandirian yang harus diinternalisasikan dalam kesatuan karakter individu eks psikotik.

Masalah seperti gangguan eks psikotik ini, dinas UPT Rehabilitasi Sosial eks psikotik provinsi Jawa Timur di Caruban, belum banyak diketahui keberadaannya oleh masyarakat, peran dari pihak masyarakat belum banyak memberikan sumbangsih kepada dinas terkait. Masyarakat cenderung apatis, sehingga mempengaruhi proses perkembangan sosial penderita eks psikotik. Melalui program ini, kami tim peneliti berusaha membantu memberikan pelatihan ketrampilan hidup guna kemajuan dan peningkatan segi kemandirian sosial ekonomi. Selain itu, untuk langkah selanjutnya kami berusaha menunjukkan keberadaan dinas UPT Rehabilitasi Sosial eks psikotik Kediri kepada seluruh pihak masyarakat, sehingga masyarakat dapat membantu dan berperan serta dalam rehabilitasi individu eks psikotik.

Enung Fatimah (2006:141) menyatakan kemandirian atau sering juga disebut berdiri diatas kaki sendiri merupakan kemampuan seseorang untuk tidak bergantung pada orang lain serta bertanggung jawab atas apa yang dilakukannya.

Paul Ernest (2012) menyatakan sosial lebih dari sekedar jumlah manusia secara individu karena mereka terlibat dalam berbagai kegiatan bersama. Sedangkan Enda M.C (2012) menyatakan sosial adalah cara tentang bagaimana para individu saling berhubungan.

M. Manulang (2012) menyatakan ekonomi adalah ilmu yang mempelajari masyarakat dalam usahanya untuk mencapai kemakmuran (kemakmuran suatu keadaan dimana manusia dapat memenuhi kebutuhannya, baik barang-barang maupun jasa).

Sedangkan menurut Sundari (2005:82) psikotik adalah gangguan jiwa yang ditandai dengan ketidak-mampuan individu menilai kenyataan yang terjadi, misalnya terdapat halusinasi, waham atau perilaku kacau/aneh. 
Teknik ini dipandang sesuai dengan kondisi perkembangan sosial ekonomi saat ini yang ditandai dengan berbagai tantangan. Adanya teknik ini diharapkan individu eks psikotik mampu beradaptasi dan bersosialisasi jika kelak individu eks psikotik tersebut dinyatakan siap untuk dikembalikan ke lingkungan tempat individu tersebut tinggal. Selain itu, individu eks psikotik diharapkan memiliki ketrampilan hidup guna meningkatkan kemandirian ekonomi sehingga mendapatkan penghasilan sendiri. Hal lain yang mendukung penelitian ini adalah belum adanya penelitian sejenis yang mengkaji masalah tersebut, sehingga peneliti memandang topik ini layak dan perlu untuk direalisasikan.

\section{Kajian Pustaka}

1. Kemandirian Sosial Ekonomi

a. Pengertian Kemandirian

Kemandirian merupakan salah satu kemampuan yang harus dimiliki oleh setiap individu. Darodzat (dalam Muhammad Yaumi, 2008:27) menyatakan bahwa kemandirian adalah kecenderungan anak untuk melakukan sesuatu yang di ingini tanpa minta tolong pada orang lain, juga dapat mengarahkan kelakuannya tanpa tunduk pada orang lain.

Enung Fatimah (2006:141) menyatakan kemandirian atau sering juga disebut berdiri diatas kaki sendiri merupakan kemampuan seseorang untuk tidak bergantung pada orang lain serta bertanggung jawab atas apa yang dilakukannya.

Sedangkan menurut Bambang Ismawan (2011), kemandirian (SelfReliance) adalah suatu konsep yang sering dihubungkan dengan pembangunan yang dirancang secara sistematis agar individu maupun masyarakat menjadi subyek dari pembangunan. Sutari Imam Barnadib (dalam Desmita, 2007:142) menyatakan bahwa kemandirian meliputi perilaku mampu berinisiatif, mampu mengatasi hambatan atau masalah, mempunyai rasa percaya diri dan dapat melakukan sesuatu sendiri tanpa bantuan orang lain. Kartini dan Dali (dalam Desmita,2007:142) menyatakan bahwa kemandirian adalah hasrat untuk mengerjakan segala sesuatu bagi 
diri sendiri. Konsep kemandirian tidak harus dimiliki oleh individu secara normal, tetapi harus diupayakan pada semua individu termasuk individu eks psikotik.

b. Pengertian Sosial

Bimo Walgito (2003:57) menyatakan bahwa sosial adalah hidup bermasyarakat. Sedangkan Myers (dalam Bimo Walgito 2003:6) menyatakan bahwa sosial adalah hubungan antara individu satu dengan individu yang lain.

Lewis (2012) Sosial adalah sesuatu yang dicapai, dihasilkan dan ditetapkan dalam sehari-hari antara warga negara dan pemerintahannya. Sedangkan menurit Keith Jacobs (2012) sosial adalah sesuatu yang dibangun dan terjadi dalam sebuah situs komunitas.

Ruth Aylett (2012) menyatakan sosial adalah sesuatu yang dipahami sebagai sebuah perbedaan namun tetap inheren dan terintegrasi.

Paul Ernest (2012) menyatakan sosial lebih dari sekedar jumlah manusia secara individu karena mereka terlibat dalam berbagai kegiatan bersama. Sedangkan Enda MC (2012) menyatakan sosial adalah cara tentang bagaimana para individu saling berhubungan.

Lena Domineli (2012) menyatakan sosial adalah merupakan bagian yang utuh dari sebuah hubungan manusia sehingga membutuhkan pemakluman atas hal-hal yang bersifat rapuh di dalamnya. Sedangkan Peter (2012) menyatakan sosial adalah sesuatu yang dipahami sebagai suatu perbedaan namun tetap merupakan sebagai suatu kesatuan.

Ketrampilan sosial dalam berhubungan antar individu perlu dipahami dan diterapkan pada semua individu normal termasuk individu eks pikotik. Kemampuan interaksi sosial meliputi proses komunikasi dan keikutsertaan dan berbagai kegiatan sosial, Namun bagi individu eks psikotik kemandirian sosial perlu dibangun secara bertahap dan perlu dilatih agar mampu diterima di masyarakat secara baik.

c. Pengertian Ekonomi 
Adam Smith (2012) menyatakan bahwa ilmu ekonomi secara sistematis mempelajari tingkah laku manusia dalam usahanya untuk mengalokasikan sumber-sumber daya yang terbatas guna mencapai tujuan tertentu. Sedangkan Paul A Samuelson (2012) menyatakan ekonomi adalah mempelajari bagaimana orang memilih menggunakan sumber produksi yang langka atau terbatas untuk memproduksi berbagai komoditi dan menyalurkannya ke berbagai masyarakat untuk segera dikonsumsi.

M. Manulang (2012) menyatakan ekonomi adalah ilmu yang mempelajari masyarakat dalam usahanya untuk mencapai kemakmuran (kemakmuran suatu keadaan dimana manusia dapat memenuhi kebutuhannya, baik barang-barang maupun jasa)

Dari pendapat para ahli di atas maka dapat disimpulkan bahwa ekonomi adalah suatu usaha yang dilakukan individu untuk mempergunakan sumber daya yang ada sehingga dapat memenuhi kebutuhannya.

Jadi pengertian kemandirian sosial ekonomi adalah suatu usaha yang dilakukan individu untuk bersosialisasi dengan masyarakat dan mempergunakan sumber daya yang ada sehingga dapat memenuhi kebutuhannya tanpa bergantung pada orang lain.

\section{d. Pengertian Psikotik}

Menurut Kartini (2000: 128) psikotik adalah suatu penyakit/gangguan mental yang ditandai oleh gangguan emosional, disorientasi waktu dan ruang, disorientasi pikiran serta kepribadian dan disertai dengan delusi dan halusinasi. Delusi biasanya disebut juga waham yang memiliki arti keyakinan yang keliru, yang tetap dipertahankan sekalipun dihadapkan dengan cukup bukti tentang kekeliruannya.

Sedangkan menurut Sundari (2005:82) psikotik adalah gangguan jiwa yang ditandai dengan ketidak mampuan individu menilai kenyataan yang terjadi, misalnya terdapat halusinasi, waham atau perilaku kacau/aneh.

Menurut Kamus Psikologi (2010: 775) psikotik sering berkaitan dengan psikotik disorder. Sering dalam bentuk kombinasi untuk menandai 
gangguan spesifik ketika simtom-simtomnya sangat mirip dengan psikosis depresi.

Dari pendapat ahli tersebut di atas dapat disimpulkan waham adalah gangguan jiwa yang ditandai adanya gangguan emosi, pikiran dan kenyataan yang ada.

Ciri-ciri Psikotik

Menurut Kartini (2000: 129) Individu yang mengalami psikotik memiliki ciri-ciri sebagai berikut antara lain:

1. Adanya kepecahan pribadi dan mental yang progresif

2. Tidak adanya wawasana

3. Adanya maladjustment

4. Dibayangi oleh macam-macam halusinasi dan delusi

5. Menjadi agresif, kasar, keras kepala bahwan menjadi eksplosif meledak-ledak.

\section{Kecakapan Vokasional}

a. Pengertian Kecakapan Vokasional

Kecakapan vokasional adalah salah satu bentuk kecakapan spesisfik yang mengarah pada kemampuan individu dalam bekerja atau mewujudkan suatu karya. Menurut Dinas Pendidikan (2011:7), kecakapan vokasional disebut juga kecakapan kejuruan, yaitu kecakapan yang dikaitkan dengan bidang pekerjaan tertentu yang terdapat di masyarakat. Kecakapan ini lebih cocok untuk individu yang akan menekuni pekerjaan yang lebih mengandalkan keterampilan psikomotor.

Dede Supriyanto (2012) vokasional dikenal hanya dalam arti sempit yaitu berarti pekerjaan sehingga pelaksanaannya hanya dalam saat-saat yang sifatnya temporer atau bila individu membutuhkannya.

Dewa Ketut Sukardi (2003:51) kecakapan vokasi adalah pemilihan kecakapan area kejuruan. Munandir (1996:147) kecakapan vokasional adalah ketertarikan orang terhadap minat taraf profesional, minat komersial, minat kegiatan fisik. 
Arthur dan Emily (2010:1040) kecakapan pemilihan vokasional adalah proses yang mengupayakan pemilihan seseorang kepada kemungkinan tertinggi untuk berhasil dalam pekerjaan tertentu.

b. Jenis Kecakapan Vokasional

Dari beberapa pendapat diatas disimpulkan bahwa kecakapan vokasional adalah keahlian individu untuk memilih bidang pekerjaan sesuai dengan bakat yang dimiliki.

Kecakapan vokasional meliputi :

1) Kecakapan Vocasional Dasar (Basic Vocational Skill)

Yang termasuk kecakapan vokasional dasar antara lain: kecakapan melakukan gerak dasar, menggunakan alat sederhana, atau kecakapan membaca gambar.

2) Kecakapan Vocational Khusus (Occupational Skill)

Kecakapan ini memiliki prinsip dasar menghasilkan barang atau jasa. Sebagai contoh, kecakapan memperbaiki mobil bagi yang menekuni bidang otomotif dan meracik bumbu bagi yang menekuni bidang tata boga.

c. Konsep Kecakapan Vocational

Menurut konsepnya, kecakapan hidup dapat dibagi menjadi dua jenis utama, yaitu:

1) Kecakapan hidup generik (generic hold up skill/GLS)

Kecakapan hidup generik terdiri atas kecakapan personal (personal skill), dan kecakapan sosial (social skill). Kecakapan personal mencakup kecakapan dalam memahami diri (self recognition skill) dan kecakapan berpikir (thinking skill). Kecakapan mengenal diri pada dasarnya merupakan penghayatan diri sebagai makhluk Tuhan Yang Maha Esa, sebagai anggota masyarakat dan warga negara, serta menyadari dan mensyukuri kelebihan dan kekurangan yang dimiliki sekaligus sebagai modal dalam meningkatkan dirinya sebagai individu yang bermanfaat bagi lingkungannya. Kecakapan berpikir mencakup antara lain kecakapan mengenali dan menemukan informasi, 
mengolah, dan mengambil keputusan, serta memecahkan masalah secara kreatif. Sedangkan dalam kecakapan sosial mencakup kecakapan berkomunikasi (communication skill) dan kecakapan bekerjasama (collaboration skill).

2) Kecakapan hidup spesifik (specific hold up skill/SLS).

Kecakapan hidup spesifik adalah kecakapan untuk menghadapi pekerjaan atau keadaan tertentu. Kecakapan ini terdiri dari kecakapan akademik (academic skill) atau kecakapan intelektual, dan kecakapan vokasional (vocational skill). Kecakapan akademik terkait dengan bidang pekerjaan yang lebih memerlukan pemikiran atau kerja intelektual. Kecakapan vokasional terkait dengan bidang pekerjaan yang lebih memerlukan keterampilan motorik. Kecakapan vokasional terbagi atas kecakapan vokasional dasar (basic vocational skill) dan kecakapan vokasional khusus (occupational skill).

Menurut konsep di atas, kecakapan hidup adalah kemampuan dan keberanian untuk menghadapi problema kehidupan, kemudian secara proaktif dan kreatif mencari dan menemukan solusi untuk mengatasinya. Pendidikan berorientasi kecakapan hidup bagi peserta didik adalah sebagai bekal dalam menghadapi dan memecahkan problema hidup dan kehidupan, baik sebagai pribadi yang mandiri, warga masyarakat, maupun sebagai warga negara. Apabila hal ini dapat dicapai, maka ketergantungan terhadap ketersediaan lapangan pekerjaan, yang berakibat pada meningkatnya angka pengangguran, dapat diturunkan, yang berarti produktivitas nasional akan meningkat secara bertahap.

Pembahasan tentang kecakapan hidup tidak akan terlepas dari konsep tentang kompetensi atau pendidikan berbasis kompetensi. Konsep kecakapan hidup mempunyai makna yang sama dengan kompetensi. Sebagaimana dikemukakan oleh Nana Syaodih (2004: 29-30) bahwa secara umum kompetensi mempunyai makna yang hampir sama dengan kecakapan hidup atau "life skill", yaitu kecakapan-kecakapan, keterampilan untuk 
menyatakan, memelihara, menjaga dan mengembangkan diri. Kecakapan dan keterampilan-keterampilan tersebut, tidak sekedar berkenaan dengan aspek fisik-biologis, tetapi juga aspek intelektual, sosial, dan afektif (perasaan, sikap, nilai).

Kompetensi atau keterampilan hidup dinyatakan dalam kecakapan, kebiasaan, keterampilan, kegiatan, perbuatan atau performansi yang dapat diamati malahan dapat diukur. Performansi merupakan unsur yang nampak atau "overt" dari performansi, tetapi di belakang yang nampak tersebut banyak unsur-unsur yang tidak nampak atau "covert". Suatu kompetensi apalagi kalau kompetensi tersebut berkenaan dengan kompetensi tahap tinggi minimal aspek, yaitu pengetahuan, keterampilan, proses berpikir, penyesuaian diri, sikap dan nilai-nilai.

Aspek-aspek Kompetensi (Keterampilan Hidup) menurut Nana Syaodih S. (2004:30) bahwa pengetahuan, keterampilan berpikir, proses berpikir, penyesuaian diri, sikap dan nilai sukar diamati atau diukur karena tersembunyi, tetapi manifestasinya atau penerapannya dalam berbagai situasi nyata dapat diamati atau diukur. Walaupun pemahaman proses berpikir, sikap dan lain-lain itu tidak bisa dilihat tetapi pengaruhnya terhadap performansi dapat dilihat.

Berdasarkan uraian di atas, maka keterampilan hidup (life skill) dapat diartikan sebagai suatu keberanian menghadapi problema hidup dan kehidupan secara wajar tanpa merasa tertekan, kemudian secara kreatif menemukan solusi serta mampu mengatasinya (Depdiknas, 2002: 1-7).

Pendidikan kecakapan hidup dalam pendidikan luar sekolah ditekankan pada learning and earning maksudnya bahwa pendidikan luar sekolah menekankan pada proses belajar yang mengarah pada pembentukan pengetahuan dan keterampilan dan kebutuhan masyarakat guna memecahkan permasalahan-permasalahan yang dirasakan dan kebutuhan mendesak masyarakat, juga perkembangan sosial yang terjadi. Sedangkan jenis kecakapan hidup lainnya meliputi aspek proses berpikir dan 
penyesuaian diri juga diperlukan dalam pendidikan luar sekolah, namun pendidikan luar sekolah lebih menekankan pada aspek learning dan earning, belajar sangat butuh proses berpikir dan penyesuaian diri sehingga earning pun dapat selaras dengan nilai-nilai dan norma masyarakat maupun agama.

Tujuan pendidikan kecakapan hidup dalam pendidikan luar sekolah adalah untuk membentuk masyarakat dan menanggulangi permasalahan pendidikan, sehingga dapat tercapai masyarakat yang memiliki pengetahuan dan keterampilan sebagai bekal hidup dalam keseharian dan dunia kerja, yang akhirnya dapat membentuk suatu masyarakat belajar dan masyarakat yang berpengetahuan.

Metode Penelitian

Penelitian ini menggunakan metode studi kasus dengan pendekatan studi lapangan (field research) yang dipadukan dengan studi pustaka (library research). Studi Lapangan (field research) yaitu kegiatan mencari data yang dilakukan langsung terjun ke lapangan di rehabilitasi dinas sosial propinsi jawa timur. Studi Pustaka (library research) yaitu suatu kegiatan mempelajari buku-buku literatur dan sumber lain yang mendukung penelitian ini.

Sasaran penelitian adalah individu eks psikotik berjenis kelamin laki-laki sejumlah 70 orang, dengan menggunakan teknik purposive sampling.

Lokasi penelitian adalah UPT Rehabilitasi Sosial Eks Psikotik (RESP) Dinas Sosial Propinsi Jawa Timur dengan alamat Desa Kaliabu Kecamatan Mejayan Kabupaten Madiun.

Analisis data dilakukan melalui pendekatan deskriptif kualitatif dengan menyesuaikan dan menggabungkan alternatif pemecahan masalah dan ide kreatif dari penulis dengan berbagai kajian pustaka sehingga diperoleh suatu hasil konkrit yang dapat digunakan sebagai bahan acuan untuk selanjutnya. Penelitian ini merupakan jenis penelitian deskriptif, analisis data yang digunakan adalah analisis kualitatif dengan model analisis interaktif.

\section{Hasil Dan Pembahasan}


Penelitian ini dimulai pada bulan Januari sampai dengan bulan Desember 2014. Hasil yang telah dicapai dalam penelitian ini, yaitu tersusun instrument penelitian berupa lembar observasi kemandirian sosial ekonomi sosial ekonomi individu eks psikotik. Lembar observasi ini mengamati beberapa indikator antara lain :

1. Individu eks psikotik mampu membuat kerajinan keset.

2. Individu eks psikotik mampu membuat kerajinan dari kayu

3. Individu eks psikotik siap dikembalikan ke keluarga dan masyarakat.

4. Individu eks psikotik bertanggungjawab dengan apa yang diperbuatnya.

Di dalam penelitian ini disajikan hasil observasi dari setiap siklus, penyajian data yang sudah dikumpulkan adalah sebagai berikut:

1. Observasi individu eks psikotik di UPT Rehabilitasi Sosial Eks Psikotik Dinas Sosial Propinsi Jawa Timur dengan mengamati dan mendata individu yang mempunyai perilaku yang tidak rasional di UPT Rehabilitasi Sosial Eks Psikotik Dinas Sosial Propinsi Jawa Timur. Misalnya; individu mudah tersinggung dan langsung marah dengan reaksi yang over apabila mendapatkan kritik dan gangguan dari individu yang lain, individu tidak aktif dalam kegiatan ketrampilan.

2. Membagi siswa dalam kelompok sesuai dengan masalah yang dihadapi dengan mengelompokan individu eks psikotik berdasarkan minat, ketrampilan dan kemauan.

3. Observasi pre treatment 
Tabel 3.1 Ketrampilan Pre-Test

\begin{tabular}{|c|c|c|c|c|c|c|}
\hline No & Nama & Usia & Kriteria & Mampu & Tidak Mampu & Ket \\
\hline 1 & Roni Siswanto & 23 & B & & $\checkmark$ & \\
\hline 2 & Rudiono & 30 & $\mathrm{~B}$ & & $\sqrt{\checkmark}$ & \\
\hline 3 & Rio Dwi Armada & 21 & $\mathrm{~B}$ & & $\checkmark$ & \\
\hline 4 & Rahmat Hidayat & 34 & B & & $\checkmark$ & \\
\hline 5 & Suhadi & 42 & $\mathrm{~B}$ & & $\sqrt{\checkmark}$ & \\
\hline 6 & Candra Nur F & 51 & $\mathrm{~B}$ & & $\checkmark$ & \\
\hline 7 & Riski Nurdiansyah & 44 & B & & $\checkmark$ & \\
\hline 8 & Aldy J & 24 & B & & $\checkmark$ & \\
\hline 9 & Moh Aji Saputro & 21 & $\mathrm{~B}$ & & $\checkmark$ & \\
\hline 10 & Bektiningrum $\mathrm{P}$ & 35 & B & & $\checkmark$ & \\
\hline 11 & Lucky Wibowo & 33 & $\mathrm{~B}$ & & $\checkmark$ & \\
\hline 12 & Rhagiel Egi F & 33 & $\mathrm{~B}$ & & $\checkmark$ & \\
\hline 13 & Rivian & 33 & B & & $\checkmark$ & \\
\hline 14 & Bagus Aditya & 34 & B & & $\checkmark$ & \\
\hline 15 & Yoga Wahyu P & 30 & B & & $\checkmark$ & \\
\hline 16 & Jefrianto & 41 & B & $\checkmark$ & & \\
\hline 17 & Sutrisno & 52 & B & & $\checkmark$ & \\
\hline 18 & Wicaksono & 60 & $\mathrm{~B}$ & & $\checkmark$ & \\
\hline 19 & Agil Rian & 52 & B & & $\checkmark$ & \\
\hline 20 & Ostar Romadhon & 51 & B & & $\checkmark$ & \\
\hline 21 & Dinar Cahya & 29 & $\mathrm{~B}$ & & $\checkmark$ & \\
\hline 22 & Marsela & 28 & B & & $\checkmark$ & \\
\hline 23 & Nurulia Dwi & 26 & $\mathrm{~S}$ & & $\checkmark$ & \\
\hline 24 & Ika Yunia & 27 & $\mathrm{~S}$ & & $\checkmark$ & \\
\hline 25 & Bintoro & 46 & $\mathrm{~S}$ & $\checkmark$ & & \\
\hline 26 & Misilah & 62 & $\mathrm{~S}$ & & $\checkmark$ & \\
\hline 27 & Puji Lestari & 39 & $\mathrm{~S}$ & $\checkmark$ & & \\
\hline 28 & Ahmad Boas & 48 & $\mathrm{~S}$ & $\checkmark$ & & \\
\hline 29 & Dwi Retno & 37 & $\mathrm{~S}$ & & $\checkmark$ & \\
\hline 30 & Kasno & 51 & $\mathrm{~S}$ & $\checkmark$ & & \\
\hline 31 & Dian Agus & 40 & $\mathrm{R}$ & $\checkmark$ & & \\
\hline 32 & Marsini & 33 & $\mathrm{R}$ & $\checkmark$ & & \\
\hline 33 & Wati Eka & 50 & $\mathrm{R}$ & $\checkmark$ & & \\
\hline 34 & Guntari & 53 & $\mathrm{R}$ & $\checkmark$ & & \\
\hline 35 & Misidi & 57 & $\mathrm{R}$ & $\checkmark$ & & \\
\hline 36 & Yayuk S & 43 & $\mathrm{R}$ & & $\checkmark$ & \\
\hline 37 & Totok Sugiarto & 38 & $\mathrm{R}$ & & $\checkmark$ & \\
\hline 38 & Yayuk D N & 36 & $\mathrm{R}$ & & $\sqrt{\checkmark}$ & \\
\hline 39 & Ponimin & 56 & $\mathrm{R}$ & & $\checkmark$ & \\
\hline 40 & Tugiyarno & 39 & $\mathrm{R}$ & & $\checkmark$ & \\
\hline 41 & Sukadi & 61 & $\mathrm{R}$ & & $\sqrt{\checkmark}$ & \\
\hline 42 & Angela V & 23 & $\mathrm{R}$ & $\sqrt{\checkmark}$ & & \\
\hline 43 & Suyadi & 54 & $\mathrm{R}$ & $\checkmark$ & & \\
\hline 44 & Sadirah & 56 & $\mathrm{R}$ & & $\checkmark$ & \\
\hline 45 & Karna & 18 & $\mathrm{R}$ & $\checkmark$ & & \\
\hline 46 & Lugimin & 54 & $\mathrm{R}$ & & $\checkmark$ & \\
\hline 47 & Moh Nasir & 18 & $\mathrm{R}$ & $\checkmark$ & & \\
\hline 48 & Saidi & 19 & $\mathrm{R}$ & & $\checkmark$ & \\
\hline 49 & Roni Permana & 23 & $\mathrm{R}$ & & $\checkmark$ & \\
\hline 50 & Meykha Selli & 32 & $\mathrm{R}$ & & $\checkmark$ & \\
\hline 51 & Handayani & 45 & $\mathrm{R}$ & & $\checkmark$ & \\
\hline
\end{tabular}




\begin{tabular}{|l|l|c|c|c|c|c|}
\hline 52 & Yuni K & 46 & R & & $\checkmark$ & \\
\hline 53 & Philips N & 32 & R & & $\checkmark$ & \\
\hline 54 & Suprihadiyono & 56 & R & & $\checkmark$ & \\
\hline 55 & Endang H & 55 & R & & $\checkmark$ & \\
\hline 56 & Luluk S & 39 & R & & $\checkmark$ & \\
\hline 57 & Doni Rahman P & 41 & R & $\checkmark$ & & \\
\hline 58 & Bachtiar R & 38 & R & $\checkmark$ & & \\
\hline 59 & Bayu Kristanto & 35 & R & & $\checkmark$ & \\
\hline 60 & Samuji & 54 & R & & & \\
\hline 61 & Mulyadi & 34 & R & & & \\
\hline 62 & Sri Wijati & 60 & R & $\checkmark$ & & \\
\hline 63 & Charles & 26 & R & $\checkmark$ & & \\
\hline 64 & Budi Winogo & 51 & R & $\checkmark$ & & \\
\hline 65 & Arif S & 47 & R & $\checkmark$ & & \\
\hline 66 & Lukash P & 37 & R & & & \\
\hline 67 & Djayusman & 60 & R & $\checkmark$ & & \\
\hline 68 & Suwondo & 43 & R & $\checkmark$ & & \\
\hline 69 & Darsini & 45 & R & $\checkmark$ & & \\
\hline 70 & Alvian & 24 & R & $\checkmark$ & & \\
\hline
\end{tabular}


Keterangan :

B : Berat

S : Sedang

$\mathrm{R}$ : Rendah

4. Treatment berupa pelatihan kecakapan vokasional (kerajinan kayu, menjahit, kerajinan keset, seni).Dalam pemecahan masalah secara individu, konselor sebagai peneliti mengarahkannya sehingga dapat dilaksindividu eks psikotikan dengan baik.

5. Observasi post treatment 
Tabel 3.2 Ketrampilan Post-Test

\begin{tabular}{|c|c|c|c|c|c|c|}
\hline No & Nama & Usia & Kriteria & Mampu & Tidak Mampu & Ket \\
\hline 1 & Roni Siswanto & 23 & $\mathrm{~B}$ & $\checkmark$ & & \\
\hline 2 & Rudiono & 30 & $\mathrm{~B}$ & $\checkmark$ & & \\
\hline 3 & Rio Dwi Armada & 21 & $\mathrm{~B}$ & & $\checkmark$ & \\
\hline 4 & Rahmat Hidayat & 34 & $\mathrm{~B}$ & & $\checkmark$ & \\
\hline 5 & Suhadi & 42 & $\mathrm{~B}$ & & $\checkmark$ & \\
\hline 6 & Candra Nur F & 51 & $\mathrm{~B}$ & $\checkmark$ & & \\
\hline 7 & Riski Nurdiansyah & 44 & $\mathrm{~B}$ & & $\checkmark$ & \\
\hline 8 & Aldy J & 24 & $\mathrm{~B}$ & $\checkmark$ & & \\
\hline 9 & Moh Aji Saputro & 21 & B & $\checkmark$ & & \\
\hline 10 & Bektiningrum $\mathrm{P}$ & 35 & $\mathrm{~B}$ & $\checkmark$ & & \\
\hline 11 & Lucky Wibowo & 33 & $\mathrm{~B}$ & & $\checkmark$ & \\
\hline 12 & Rhagiel Egi F & 33 & B & & $\checkmark$ & \\
\hline 13 & Rivian & 33 & B & & $\checkmark$ & \\
\hline 14 & Bagus Aditya & 34 & B & & $\checkmark$ & \\
\hline 15 & Yoga Wahyu P & 30 & B & $\checkmark$ & & \\
\hline 16 & Jefrianto & 41 & $\mathrm{~B}$ & & $\checkmark$ & \\
\hline 17 & Sutrisno & 52 & B & $\checkmark$ & & \\
\hline 18 & Wicaksono & 60 & B & & $\checkmark$ & \\
\hline 19 & Agil Rian & 52 & B & & $\checkmark$ & \\
\hline 20 & Ostar Romadhon & 51 & B & & $\checkmark$ & \\
\hline 21 & Dinar Cahya & 29 & B & & $\checkmark$ & \\
\hline 22 & Marsela & 28 & B & & $\checkmark$ & \\
\hline 23 & Nurulia Dwi & 26 & $\mathrm{~S}$ & $\checkmark$ & & \\
\hline 24 & Ika Yunia & 27 & $\mathrm{~S}$ & $\checkmark$ & & \\
\hline 25 & Bintoro & 46 & $\mathrm{~S}$ & $\checkmark$ & & \\
\hline 26 & Misilah & 62 & $\mathrm{~S}$ & $\checkmark$ & & \\
\hline 27 & Puji Lestari & 39 & $\mathrm{~S}$ & & $\checkmark$ & \\
\hline 28 & Ahmad Boas & 48 & $\mathrm{~S}$ & $\checkmark$ & & \\
\hline 29 & Dwi Retno & 37 & $\mathrm{~S}$ & $\checkmark$ & & \\
\hline 30 & Kasno & 51 & $\mathrm{~S}$ & $\checkmark$ & & \\
\hline 31 & Dian Agus & 40 & $\mathrm{R}$ & $\checkmark$ & & \\
\hline 32 & Marsini & 33 & $\mathrm{R}$ & $\checkmark$ & & \\
\hline 33 & Wati Eka & 50 & $\mathrm{R}$ & $\checkmark$ & & \\
\hline 34 & Guntari & 53 & $\mathrm{R}$ & $\checkmark$ & & \\
\hline 35 & Misidi & 57 & $\mathrm{R}$ & $\checkmark$ & & \\
\hline 36 & Yayuk S & 43 & $\mathrm{R}$ & $\checkmark$ & & \\
\hline 37 & Totok Sugiarto & 38 & $\mathrm{R}$ & $\checkmark$ & & \\
\hline 38 & Yayuk D N & 36 & $\mathrm{R}$ & $\checkmark$ & & \\
\hline 39 & Ponimin & 56 & $\mathrm{R}$ & $\checkmark$ & & \\
\hline 40 & Tugiyarno & 39 & $\mathrm{R}$ & $\checkmark$ & & \\
\hline 41 & Sukadi & 61 & $\mathrm{R}$ & $\checkmark$ & & \\
\hline 42 & Angela V & 23 & $\mathrm{R}$ & $\checkmark$ & & \\
\hline 43 & Suyadi & 54 & $\mathrm{R}$ & $\checkmark$ & & \\
\hline 44 & Sadirah & 56 & $\mathrm{R}$ & $\checkmark$ & & \\
\hline 45 & Karna & 18 & $\mathrm{R}$ & $\checkmark$ & & \\
\hline 46 & Lugimin & 54 & $\mathrm{R}$ & $\checkmark$ & & \\
\hline
\end{tabular}




\begin{tabular}{|l|l|l|l|c|l|l|}
\hline 47 & Moh Nasir & 18 & R & $\checkmark$ & & \\
\hline 48 & Saidi & 19 & R & $\checkmark$ & & \\
\hline 49 & Roni Permana & 23 & R & $\checkmark$ & & \\
\hline 50 & Meykha Selli & 32 & R & $\checkmark$ & & \\
\hline 51 & Handayani & 45 & R & $\checkmark$ & & \\
\hline 52 & Yuni K & 46 & R & $\checkmark$ & & \\
\hline 53 & Philips N & 32 & R & $\checkmark$ & & \\
\hline 54 & Suprihadiyono & 56 & R & $\checkmark$ & & \\
\hline 55 & Endang H & 55 & R & $\checkmark$ & & \\
\hline 56 & Luluk S & 39 & R & $\checkmark$ & & \\
\hline 57 & Doni Rahman P & 41 & R & $\checkmark$ & & \\
\hline 58 & Bachtiar R & 38 & R & $\checkmark$ & & \\
\hline 59 & Bayu Kristanto & 35 & R & $\checkmark$ & & \\
\hline 60 & Samuji & 54 & R & $\checkmark$ & & \\
\hline 61 & Mulyadi & 34 & R & $\checkmark$ & & \\
\hline 62 & Sri Wijati & 60 & R & $\checkmark$ & & \\
\hline 63 & Charles & 26 & R & $\checkmark$ & & \\
\hline 64 & Budi Winogo & 51 & R & $\checkmark$ & & \\
\hline 65 & Arif S & 47 & R & $\checkmark$ & & \\
\hline 66 & Lukash P & 37 & R & $\checkmark$ & & \\
\hline 67 & Djayusman & 60 & R & $\checkmark$ & & \\
\hline 68 & Suwondo & 43 & R & $\checkmark$ & & \\
\hline 69 & Darsini & 45 & R & $\checkmark$ & & \\
\hline 70 & Alvian & 24 & R & $\checkmark$ & & \\
\hline
\end{tabular}

\section{Keterangan :}

$\mathrm{B}:$ Berat
$\mathrm{S}$ : Sedang
$\mathrm{R}$ : Rendah

Berdasarkan tabel diatas menunjukkan bahwa kemandirian sosial ekonomi individu eks psikotik mulai dari observasi sampai pelatihan kecakapan vokasional yang pertama terjadi kenaikan pada setiap indikator. Hal ini menunjukkan bahwa melalui pelatihan kecakapan vokasional dapat meningkatkan kemandirian sosial ekonomi individu eks psikotik di UPT Rehabilitasi Sosial Eks Psikotik Dinas Sosial Propinsi Jawa Timur, Desa Kaliabu, Kec. Mejayan, Kab. Madiun. 


\section{Kesimpulan}

Berdasarkan hasil penelitian di atas diperoleh simpulan, bahwa pelatihan kecakapan vokasional efektif untuk meningkatkan kemandirian sosial ekonomi individu eks psikotik di UPT Rehabilitasi Sosial Eks Psikotik Dinas Sosial Provinsi Jawa Timur.

\section{Daftar Pustaka}

Bimo Walgito. 2003. Psikologi Sosial. Jakarta: Rineka Cipta.

Carapedia.com/pengertian definisi ilmu ekonomi menurut para ahli info490.ht ml. (online, diakses tanggal 02 Agustus 2012)

Desmita. 2009. Psikologi Perkembangan Peserta didik.. Bandung: Rosdakarya.

Dewa Ketut S. 1993. Psikologi Pemilihan Karier. Denpasar: Rineka Cipta.

Arthur S R dan Emily S R. 2010. Kamus Psikologi. Yogyakarta: Pustaka Belajar.

BimoWalgito. 2003. Psikologi Sosial. Jakarta: Rineka Cipta.

Carapedia.com/pengertian_definisi_ilmu_ekonomi_menurut_para_ahli_info490.html. (On Line, diaksestanggal 02 Agustus 2012)

Desmita. 2009. Psikologi Perkembangan Peserta Didik. Bandung: Rosdakarya.

Dewa Ketut Sukardi. 1993. Psikologi Pemilihan Karier. Denpasar: Rineka Cipta

Dirjen Pendidikan Menengah Umum. 2011. Program Broad Based Education (Berorientasi pada life skill). Jakarta

Kaplan H I dan Sadock B J. 1997. Sinopsis Psikiatri Edisi ke Tujuh Jilid Dua. Jakarta: Binarupa Aksara.

Kartini Kartono. 2000. Hygyene Mental. Bandung: MandarMaju.

Muhammad Yaumi. 2012. Kemandirian sebagai Kebutuhan psikologi pada remaja (online), http://topmotivasimandiri. Blog12.com, diakses tanggal 2 Agustus 2012-08-06.

Munandir. 1996. Program Bimbingan Karir di Sekolah. Jakarta: Dikti

Paul Ernest. 2012. Pengertian_definisi_sosial_info490.html(online), diakses tanggal 2 Agustus 2012-08-06

Ruth Aylett. 2009. Mengenal Diri Sendiri (online), (img/artikel/12_20120709131745.jpg. diakses tanggal 2 Agustus 2012

Siti Sundari. 2005. Kesehatan Mental dalam Kehidupan. Jakarta: Rineka Cipta.

Sugiyono. 2007. Metode Penelitian Kuantitatif, Kualitatif dan R\&D. Bandung: Alfa Beta.

Suharsimi Arikunto. 2002. Prosedur Penelitian Suatu Pendekatan Praktek. Jakarta: Asdi Mahasatya.

Suryabrata, S. 2003. Metodologi Penelitian. Jakarta: PT Raja Grafindo Persada. 
